not given from birth, but that is formed and developed in the process of professional training, the life safety culture of future primary school teachers presents as an object of pedagogical research.

According to the results of the experiment, it was found that the criterion measures are of professional-quality signs of readiness to realization of professional competences in the process of professional activity. The determination of the professional competence development of future primary school teachers is carried out according to criteria that reflect the essence of its components. The indicators of each criterion are determined by us on the basis of the essence of the corresponding component of professional competence of future primary school teachers in higher educational institutions.

For the effective implementation of the technology of forming a culture of life safety for future primary school teachers in the process of vocational training, diagnosing the achievement of the result of a competen-oriented educational process using a criteria-based approach, the following criteria are defined: cognitive, motivational-valueable, practical, reflective, which have corresponding qualitative indicators

According to the results of the research, it was determined the initial level of organization of professional training of future primary school teachers, the main factors affecting the development of professionally important personal qualities.

Keywords: primary school teacher, life safety culture, criteria, levels.

DOI: https://doi.org/10.31392/NZ-npu-145.2019.9

УДК 37.014.3:37.011.3-051

Матвієнко О.В.

\title{
АКТУАЛЬНІ ПРОБЛЕМИ \\ ФОРМУВАННЯ ПЕДАГОГІЧНОЇ ПОЗИЦІЇ ВЧИТЕЛЯ В УМОВАХ РЕФОРМУВАННЯ СИСТЕМИ ОСВІТИ
}

У статті автор наводить аналіз вимог сучасної освітньої політики до професіоналізму вчителя $і$ теоретично обтрунтовує особливості формування педагогічної позиції вчителя як показника його професіоналізму у взаємодії з учнем. Проаналізувавши психолого-педагогічну літературу з теми дослідження, з'ясовано, щзо на сучасному етапі реформування системи освіти, одним з орієнтирів стає оновлення змісту професійної діяльності вчителя.

Ключові слова: професіоналізм, педагогічна позиція, державний стандарт, вчитель, педагогічна освіта, педагогічна взаємодія, освітня політика.

На сучасному етапі розбудови незалежної української держави питання становлення і розвитку педагогічної освіти стають дедалі суттєвішими для визначення стратегії й тактики входження до нового європейського освітнього простору. Адже сьогодні Україна переживає складний період рефрормаційних перетворень у галузі освіти, намагаючись вийти на рівень світових освітніх стандартів. Положення законів України “Про освіту" (2017р.), "Про вищу освіту" (2014р.), "Національної стратегії розвитку освіти в Україні на період до 2021 року" (2013 р.) та Концепції реалізації державної політики у сорері реформування загальної середньої освіти "Нова українська школа" на період 
до 2029 року (2016р.) визначають нові вимоги щодо професійного рівня і педагогічної майстерності майбутнього вчителя. Відповідно до положень Концепції "Нова українська школа": “Тільки освічена людина може бути справді вільною. Європейське суспільство, до якого ми прагнемо, - це суспільство освіченого загалу, суспільство високої культури і рівних можливостей. Таке суспільство забезпечує європейську якість життя" [1].

Одним 3 орієнтирів стає оновлення змісту освіти. Серед стратегічних завдань його реформування $€$ розробка державних стандартів і відповідне формування системи та обсягу знань, умінь, навичок творчої діяльності, інших якостей особистості на різних освітніх та кваліфікаційних рівнях. Інакше кажучи, вибрано курс на стандартизацію педагогічної освіти.

Нові освітні цілі і завдання та новий зміст початкової освіти вимагають використання нових технологій навчання, нових методичних прийомів організації навчального процесу, які б базувались на сучасних досягненнях психолого-педагогічної науки та свідомій і творчій діяльності вчителя.

Сучасні наукові підходи до висвітлення аспектів проблеми професійнопедагогічної підготовки фахівців 3 вищою освітою відображено у напрацюваннях В. Бондаря, І. Зязюна, О. Савченко, Н. Ничкало та інших. Так, сучасна педагогічна освіта знімає обмеження 3 індивідуума як пасивного споживача і дає йому змогу зайняти місце в суспільстві відповідно до особистих вимог та індивідуальних якостей. Нормативні документи щодо стандартизації, просякнуті суб'єктнодіяльнісним підходом, вимагають реалізації принципів цілеспрямованості, прогностичності, технологічності та діагностичності.

Аналіз інформаційних джерел у галузі освіти виявляє, що в теорії та практиці професійної підготовки майбутніх учителів накопичено значний потенціал: розроблено теоретичні й методичні основи неперервної профресійної освіти (В. Луговий, С. Сисоєва та інші); досліджено проблеми професійної підготовки учителів у системі вищої педагогічної освіти (В. Бобрицька, О. Лавриненко, В.Ягупов та інші). Різноманітні аспекти профресійної підготовки майбутніх учителів початкової школи висвітлено у працях О. Матвієнко, С. Мартиненко, М. Марусинець, Л. Петухової, М. Севастюк, І. Шапошнікової, Л. Хомич та інших. Відтак, аналіз вітчизняної і зарубіжної літератури, врахування наявного практичного педагогічного досвіду засвідчують, що стан готовності особистості до виконання професійнопедагогічної діяльності забезпечує не тільки її ефективність, але й можливості подальшого самовдосконалення, а відбір та структурування змісту освіти, зокрема фахової, $€$ однією з найбільш складних, визначальних проблем педагогіки вищої освіти.

Одне з ключових завдань, яке вирішується в сучасній освіті, є кадрове забезпечення освітніх процесів, а розв'язанню цієї задачі допомагає система безперервної педагогічної освіти. Постановка цілей підготовки, перепідготовки і підвищення кваліфікації педагогічних кадрів здійснюється на основі уявлення про професіоналізм педагога, який постійно 
удосконалюється, коригується, завдяки дослідженням учених - педагогів і психологів, а також у зв'язку зі змінами в соціумі та культурі.

Оскільки детальний історико-педагогічний аналіз не входить до завдань цієї статті, обмежимося висновком про те, що традиційна освіта спиралася на дослідження, що виконуються в руслі професіографрічного підходу. Для цього підходу характерні розробки нормативних моделей особистості й діяльності педагога, в яких представлені вимоги до педагога з погляду професійних функцій та їх соціальної значущості й не відображені внутрішні, суб'єктивні аспекти професіоналізму. На наш погляд, уявлення про усі аспекти професіоналізму з точки зору відповідності педагога соціальним вимогам виражене в професіограмі А. Маркової. У цій профресіограмі представлені професійні завдання, професійні й психологічні знання, профресійні дії, психологічні уміння, якості особистості, результати професійної діяльності.

Проте при великій науковій розробленості професіографічного підходу на практиці його ідеї використовуються на рівні активності окремих викладачів, а на інституціональному рівні вони не отримали повного поширення в організації педагогічної освіти. Відбір абітурієнтів на педагогічні спеціальності здійснюється шляхом виявлення рівня предметних знань, не проводиться психолого-педагогічна діагностика особистості на предмет її педагогічної спрямованості; освітні процеси підготовки і підвищення кваліфікації вчителів орієнтуються більшою мірою на теоретичне, а не практичне навчання, а розвиток професійно значущих особистісних якостей педагога взагалі залишається без уваги .

Причини, з одного боку, домінування професіографічного підходу в науці, а з другого - його неповна реалізація на практиці знаходимо в соціокультурних чинниках.

Метою нашої статті $€$ визначення та обґрунтування особливостей формування педагогічної позиції вчителя в умовах реформування системи освіти.

Нині ми є свідками поступового “зростання" нової, постіндустріальної епохи. Потреба сучасного динамічного суспільства в людях не лише знаючих, а й здатних самостійно отримувати необхідні знання, грамотно працювати з інформацією, самостійно, критично і творчо мислити, активно діяти, приймати рішення в нестандартних ситуаціях і брати на себе відповідальність за свої дії, не лише гнучко адаптуватися до мінливих умов життя, але й перебувати в постійному процесі саморозвитку, отже, детермінує соціальне замовлення на інноваційну освіту.

Функції вчителя в сучасному соціумі не зводяться лише до передачі школярам стандартних знань, навичок і умінь, а припускають залучення їх до активного процесу освоєння світу й відкриття та перетворення самих себе. Особливу значущість набувають завдання розвитку здібностей учнів, оволодіння ними прогресивними способами мислення й діяльності, способами постійної самоосвіти, які в умовах нестабільності суспільства, 
наростання соціальних, економічних, духовно моральних проблем забезпечать людині адаптацію до майбутнього.

Водночас, орієнтація на інноваційні процеси не може спровокувати чергову крайність - утвердження в педагогічній свідомості погляду на функцію репродукції знань як на регресивну тенденцію в освіті, як на перешкоду розвитку творчої активності дитини. Забезпечуючи прогресивний рух, освіта все ж повинна залишатися соціальним інститутом, що відповідає за збереження і трансляцію культурно-історичного досвіду, за зв'язок і спадкоємність поколінь.

Отже, педагогічний професіоналізм нового типу припускає розуміння учителем ролі предметного знання, що акумулює суспільно-історичний досвід, не лише як мету та зміст навчання, а й як засоби розвитку пізнавальних потреб і здібностей школяра, збагачення й перетворення його суб'єктного досвіду.

Проведений аналіз сучасної ситуації дає змогу побачити "замовлення" на учителя, що розділяє гуманістичні цінності і реалізовує загальнолюдську сутність освіти, сприяючи забезпеченню спадкоємності між поколіннями через відтворення кращих зразків людської культури і організацію привласнення їх учнями; “прориву” в майбутнє через створення освітнього середовища, що ініціює оволодіння прогресивними способами мислення й діяльності; зміцненню зв'язків і стосунків між людьми; розвитку духовноморального потенціалу, становленню неповторної індивідуальності кожного учня через створення умов для його самоосвіти і самореалізації.

Психолого-педагогічна наука дає відповідь на таке соціальне замовлення шляхом інтерпретації педагогічного професіоналізму за допомогою поняття "позиція" і похідних від нього понять "професійна позиція" і “педагогічна позиція”, шляхом розробки теоретичних моделей цих феноменів.

Можна підвести деякі підсумки дослідження цієї проблеми.

1. Смисловим ядром значення поняття педагогічної позиції є система ставлення педагога до різних явищ педагогічної дійсності.

2. Науковцями визначені онтологічні підстави розуміння суті педагогічної позиції.

3. Дослідниками виявлено, що педагогічна позиція, через гуманітарну специфіку педагогічної професії, одночасно $€$ як професійною, так і особистісною.

4. Експериментальною практикою накопичений і педагогічною наукою описаний великий арсенал технологічних засобів фрормування й розвитку педагогічної позиції.

Спираючись на результати досліджень попередників, ми спробували збудувати цілісну теорію формування педагогічної позиції вчителя.

Передусім, ми спробували виявити співвідношення понять “професійна позиція педагога" і "педагогічна позиція". Методологічний погляд на професійну діяльність педагога як поліструктурну, поліпредметну й 
поліфрункціональну систему, що включає не лише базову - педагогічну, а й таки види професійної діяльность, як: дослідницька, методична, проектна, управлінська. Отже, професійна позиція педагога складається з цілого комплексу позицій - педагогічної, методичної, проектувальної, організаційно-управлінської, діагностичної, дослідницької.

Таким чином, поняття “професійна позиція педагога" за обсягом значно ширше, ніж понятяя "педагогічна позиція", бо охоплює, окрім педагогічної позиції, цілу низку інших професійних позицій, перелічених вище. Педагогічна позиція $€$ базовою, вона проявляється в безпосередній взаємодії з учнем і відбиває розуміння й виконання педагогом своєї антропологічної, людинотворної місії. Змістовне наповнення інших професійних позицій педагога визначається змістом педагогічної позиції, оскільки саме вона задає суть і спрямованість взаємодії, яку професійна позиції покликані забезпечити різними засобами.

Під педагогічною позицією ми розуміємо інтеграційну характеристику свідомості, діяльності й спільності педагога з учнем, що є результатом його самовизначення й відбиває розуміння, усвідомлене прийнятя та адекватне виконання педагогом своєї місії у взаємодії з учнем. Із сутності цього поняття виведена структура педагогічної позиції, яка включає компоненти:

- розуміння вчителем вимог до нього з боку педагогічної діяльності й спільності з учнем;

- прийняття об'єктивних вимог на рівні особистісного сенсу і на цій основі визначення свого місця та функцій в діяльності й спільності;

- володіння засобами реалізації "осмислених" вимог у взаємодії з учнем.

Типологія педагогічних позицій вчителя розроблена на основі ідеї про онтологічні позиції дорослого у взаємодії 3 дитиною, висловленої Г. Цукерман і В. Слободчиковим. Залежно від змісту взаємодії автори виділяють позиції “життєві" і “культурні" та означають "місця" зустрічі, тобто місця, де реалізуються, на їхню думку, різні типи змісту взаємодії: культурні цінності й норми - у студіях, майстернях, класах, лабораторіях, аудиторіях; “життєві" - у сімейних дитячих садах і таборах. У такій інтерпретації понятя позиції починає помітно зближуватися з поняттям соціальної ролі: вчительпредметник, викладач-вихователь оздоровчого табору або дитячого дому і тому подібне - в “життєвій” позиції.

Проте в змісті взаємодії вчителя й учня в цілісному освітньому процесі можна виділити як “культурний” пласт, пов'язаний з трансляцією та засвоєнням досвіду попередніх поколінь, суспільно вироблених способів мислення й діяльності, так і “життєву” складову, в якій відбувається орієнтація дитини в основних сенсах людського життя й освоєння норм стосунків між людьми. Отже, ми не лише приймаємо розподіл позицій на “культурні” і “життєві”, а й вважаємо, що обидва типи позицій поєднуються в педагогічній позиції вчителя.

За критерієм “цілі взаємодії” (або самовідтворення дорослого в дитині, 
тобто передача йому власного досвіду, поглядів і установок, або створення чогось нового) кожен з названих раніше типів - "культурна" та "життєва" позиції - авторами розділяються ще на два, внаслідок чого виділяються чотири типи позицій дорослого: “майстер” і “учитель” (“культурні”), “батьки” і “мудрець" ("життєві").

Екстраполюючи названу типологію позицій на діяльність учителя, можна відмітити, що він у взаємодії з учнем виконує дві взаємозв'язані фрункції: адаптивну, яка забезпечує оволодіння дитиною досягненнями людської культури, відтворення у властивостях індивіда історично складених властивостей і здібностей людського роду, і розвивальну, спрямовану на створення умов для максимально вільної реалізації заданих природою здібностей і можливостей, щоб не лише підтримати самобутність в кожній дитині, а й розвинути у неї здатність до життєвого самовизначення. Така постановка питання про мету педагогічної взаємодії $\epsilon$ особливо актуальною для сучасної освіти, що все частіше як основну цінність проголошує розвиток і прагне стати як розвивальною, так і розвиваючою системою.

Якщо обидві мети - і самовідтворення, і створення нового $є$ присутніми у взаємодії вчителя й учня, то усі чотири типи позицій дорослого, виділені авторами, можна вважати типами педагогічної позиції учителя. Але, виходячи з розумінні багатофрункціональності взаємодії в діаді "учительучень", ми вважаємо, що в гуманістично спрямованій професійній свідомості учителя всі чотири виділені позиції поєднуються i переплітаються. Наприклад, не можна вважати успішним педагога, який забезпечує дітям комфортне життя (“батьки”), вчить розбиратися в собі (“мудрець"), але не забезпечує достатній рівень засвоєння ними знань і не вчить здобувати їх самостійно (неповноцінність позицій "майстер" i "вчитель"), непривабливим $є$ й педагог, який направив усі сили дитини на засвоєння програмних знань, навичок і умінь ("майстер"), абсолютно не замислюючись про те, якими втратами в емоційно-вольовій сфері часто це досягається і чи сприяють ці знання розвитку дитини (відсутність позицій “батьки", "учитель", “мудрець”) тощо.

Отже, логічно виділяти не чотири автономні одна від одної позиції, а представляти педагогічну позицію вчителя як цілісну систему, що складається з двох "культурних" (“майстер" і “учитель") і двох “життєвих" субпозицій (“батьки" і "мудрець"), що надає педагогічній позиції цілісність, виявляєте ціннісне ставлення вчителя до учня.

Відсутність цілісної педагогічної позиції веде або до експансії предметно-діяльнісного компонента на шкоду взаєминам, до концентрації уваги на проблемах переважно функціональної підготовки, на шкоду гуманітарним проблемам дітей, або до гіпертрофіії стосунків за рахунок освітнього процесу. У будь-якому випадку це веде до розриву між навчанням і вихованням, що суперечить ідеї цілісного педагогічного процесу, а також збіднює педагогічну взаємодію й може відгукнутися 
різними дитячими антропогенними синдромами .

Кожна субпозиція має структуру ізоморфно цілісної педагогічної позиції, але наповнюється своїм змістом. Зміст субпозиції "батьки" складають: розуміння педагогом особливостей адаптації дитини до природного й соціального світів; особистісний сенс взаємодії - задоволення вітальних потреб дитини, передача їй норм буття в світі; педагогічні засоби - здатність до ідентифікації, емпатії, демонстрація зразків "нормальної" поведінки. Субпозиція “мудрець” містить: розуміння функції розвитку індивідуальності учня, смислову установку на підтримку й ініціацію проявів індивідуальності, засоби реалізації цієї функції - спілкування на духовному рівні, здатність прийняти позицію співрозмовника, прийоми педагогічної підтримки, рефлексія.

У субпозиції "майстер” вчитель розуміє свою функцію адаптації учня до культури; особистісний сенс взаємодії для нього полягає в передачі учневі предметних знань, умінь і навичок; засобами реалізації цього сенсу виступають спеціальнопредметні знання вчителя й методичні уміння організації діяльності учня із засвоєння знань, умінь і навичок. Субпозиція “учитель" пов'язана з розумінням предметником власної функції розвитку особистості учня як потенційного творця культури; особистісний сенс взаємодії з ним - в розвитку здібностей; засоби - узагальнені способи мислення й діяльності, уміння організувати навчально-пошукову активність учня.

Рівень професіоналізму вчителя визначається здатністю, утримуючи в своїй педагогічній свідомості усі чотири субпозиції, кожен раз здійснювати позиційне самовизначення в певній конкретній ситуації взаємодії з учнем і на цій основі здійснювати вибирання необхідних засобів. Якщо рівень сфрормованості педагогічної позиції високий, то проблема позиційного самовизначення для вчителя полягає не у виборі переважного для нього самого виду діяльності (навчання або виховання), а у виборі адекватної субпозиції, виходячи із завдань освіти конкретного учня.

Поза сумнівом, сфера позакласної виховної роботи надає більше можливостей для реалізації “життєвих" позицій педагога, ніж процес навчання, оскільки свобода від заданості обов'язкового предметного змісту $\epsilon$ сприятливою умовою для концентрації уваги на людських почуттях і взаєминах. Проте, приймаючи ідею цілісного педагогічного процесу, ми вважаємо актуальним розгляд питання про реалізацію в освітньому процесі “життєвих" педагогічних субпозицій, разом з “культурними".

На основі моделі педагогічної позиції вчителя, а також розроблених аксіологічних, методологічних і теоретичних підстав її становлення й розвитку нами сконструйована технологія становлення цього феномену. Виходячи із структури педагогічної позиції, ми виділили напрями процесу їі становлення: а) зростання в свідомості вчителів прошарку цінностей і сенсів освіти та розвитку людини; б) збагачення у свідомості вчителів прошарку засобів педагогічної діяльності, адекватних їхнім цінностям і 
сенсам; в) поєднання цих прошарків свідомості між собою.

Теоретичною основою організації першого напряму процесу є поняття смислопобудови і смислоусвідомлення. Результатом роботи у цьому напрямі $\epsilon$ привласнені вчителями гуманістичні профресійно-особистісні цінності та їх конкретизація в різних ситуаціях педагогічної взаємодії (у субпозиціях “батьки”, “мудрець”, “майстер”, “учитель”).

Зміст другого напряму процесу складають форми організації, технології, методи, методики і прийоми взаємодії учителя й учня в різних педагогічних субпозиціях, а результатом стають інструментальні педагогічні знання.

Висновки. Аналіз літератури й реальної практики дає змогу стверджувати, що парадигма професійної освіти, спрямована на формування педагогічного професіоналізму в єдності його об'єктивних і суб'єктивних характеристик, повністю ще не склалася і представлена окремими інноваційними ініціативами, які не завжди поєднуються 3 існуючим традиційним нормативно-правовим забезпеченням освітньої сорери.

В умовах розбудови інноваційного суспільства суттєвими особливостями освіти виступає не тільки здатність надавати здобувачам освіти накопичений в попередні роки обсяг знань та навичок, але й підвищити здатність до сприйняття та практичного використання нових наукових ідей, технічних інструментів та методів виробництва, сорормувати у молодих спеціалістів мотивацію до новаторства, ініціативність та підприємливість.

У контексті приєднання України до Болонського процесу цілком природно виникла потреба реформування та вдосконалення системи освіти та іï спрямування на досягнення сучасного світового рівня, збільшення внеску в розвиток науки, освіти, культури країни й добробуту народу .

Процес стандартизації освіти сьогодні набуває особливого значення та вивчається більшістю систем освіти та впливає не лише на структуру знань, а й в цілому на якість освіти.

\section{Використана література:}

1. Закон України "Про внесення змін до Закону України "Про освіту", 2014. URL: http://zakon.rada.gov.ua.

2. Леонтьев Д. А. Динамика смысловых процессов. Психологическийжурнал. 1997. Т. 18. № 6. С. 13-27.

3. Матвієнко О.В. Педагогічне спілкування вчителя як складова професійної готовності до педагогічної взаємодії в навчально-виховному середовищі школи першого ступеня. Наукові записи Національного пед. ун-ту імені М. П. Драгоманова. Серія: Педагогічні та історичні науки: статей. Київ : Вид-во НПУ імені М. П. Драгоманова, 2011. Вип. 95. С. 123-130.

4. Матвієнко О. В. Сучасні проблеми професійної підготовки майбутніх учителів до виховної діяльності. Гуманітарний вісник - Додаток 1 до Вип. 27, Том IV (37): Тематичний випуск “Вища освіта України у контексті інтеграції до євроінтеграційного простору”. Київ : Гнозис, 2012. С. 278285.

5. Матвієнко О. В. Шляхи та умови оптимізації підготовки майбутніх учителів до педагогічної взаємодії. Психолого-педагогічні проблеми сільської школи. Уманський державний університет імені Павла Тичини, 2011. Випуск 39 (1). С. 76-86. 
6. Цвєткова Г. Г. Проблема самовдосконалення викладача вищої школи: акмеологічний, системносинергетичний, аксіологічний підходи. Духовність особистості: методологія, теорія $і$ практика. 2012. Вип. 4. С. 167-178.

7. Matviienko Olena. Pedagogical situations and tasks as means of training for professional activity. Economics, management, law: challenges and prospects: Collection of scientific articles. Psychology. Pedagogy and Education. Discovery Publishing House Pvt. Ltd., New Delhi, India. 2016. P. $204-208$.

\section{References:}

[1] Zakon Ukrainy "Pro vnesennia zmin do Zakonu Ukrainy "Pro osvitu", 2014. URL: http://zakon.rada.gov.ua.

[2] Leontev D. A. Dinamika smyslovyh processov. Psihologicheskij zhurnal. 1997. T. 18. № 6. S. 13-27.

[3] Matviienko O. V. Pedahohichne spilkuvannia vchytelia yak skladova profesiinoi hotovnosti do pedahohichnoi vzaiemodii $\mathrm{v}$ navchalno-vykhovnomu seredovyshchi shkoly pershoho stupenia. Naukovi zapysy Natsionalnoho ped. un-tu imeni M. P. Drahomanova. Seriia: Pedahohichni ta istorychni nauky: statei. Kyiv : Vyd-vo NPU imeni M. P. Drahomanova, 2011. Vyp. 95. S. 123-130.

[4] Matviienko O. V. Suchasni problemy profesiinoi pidhotovky maibutnikh uchyteliv do vykhovnoi diialnosti. Humanitarnyi visnyk - Dodatok 1 do Vyp. 27, Tom IV (37): Tematychnyi vypusk "Vyshcha osvita Ukrainy u konteksti intehratsii do yevrointehratsiinoho prostoru”. K. : Hnozys, 2012. S. 278-285.

[5] Matviienko O. V. Shliakhy ta umovy optymizatsii pidhotovky maibutnikh uchyteliv do pedahohichnoi vzaiemodii. Psykholoho-pedahohichni problemy silskoi shkoly. Umanskyi derzhavnyi universytet imeni Pavla Tychyny, 2011. Vypusk 39 (1). S. 76-86.

[6] Tsvietkova H. H. Problema samovdoskonalennia vykladacha vyshchoi shkoly: akmeolohichnyi, systemno-synerhetychnyi, aksiolohichnyi pidkhody. Dukhovnist osobystosti: metodolohiia, teoriia $i$ praktyka. 2012. Vyp. 4. S. 167-178.

[7] Matviienko Olena. Pedagogical situations and tasks as means of training for professional activity. Economics, management, law: challenges and prospects: Collection of scientific articles. Psychology. Pedagogy and Education. Discovery Publishing House Pvt. Ltd., New Delhi, India. 2016. P. 204-208.

\section{МАТвИЕНКо Е. В. Актуальные проблемы формирования педгогической позиции учителя в условиях реформирования системы образования.}

В статье автор анализирует требования современной образовательной политики $\kappa$ профессионализму учителя $и$ теоретически обосновывает особенности формирования педагогической позиции учителя как показателя его профессионализма во взаимодействии с учеником. Проанализировав психолого-педагогическую литературу по теме исследования, выяснено, что на современном этапе реформирования системы образования, одним из ориентиров становится обновление содержания профессиональной деятельности учителя.

Ключевые слова: профессионализм, педагогическая позиция, государственный стандарт, учитель, педагогическое образование, педагогическое взаимодействие, образовательная политика.

MATVIIENKO O. $V$. The actual problems of forming the teacher's pedagogical position in the conditions of the education system reform.

In the article the author gives an analysis of the requirements of modern educational policy to the teacher's professionalism and theoretically substantiates the peculiarities of forming a pedagogical position of the teacher as an indicator of his professionalism in interaction with the student. After analyzing the psychological and pedagogical literature on the subject of research, it became clear that at the current stage of reforming the education system, updating the contents of the professional activity of the teacher becomes one of the landmarks.

Keywords: professionalism, pedagogical position, state standard, teacher, pedagogical education, pedagogical interaction, educational policy. 